\title{
Oxidative Stability of Crude and Refined Kenaf (Hibiscus cannabinus L.) Seed Oil during Accelerated Storage
}

(Kestabilan Oksidatif bagi Minyak Biji Kenaf (Hibiscus cannabinus L.) Mentah dan Bertapis semasa Storan Pecut)

\author{
SOOK CHIN CHEW, CHIN PING TAN \& KAR LIN NYAM*
}

\begin{abstract}
Kenaf seed oil has been suggested to be used as edible oil but there is limited information available about the oxidative stability of refined kenaf seed oil. An oxidative stability test was performed on crude and refined kenaf seed oil under accelerated storage at $65^{\circ} \mathrm{C}$ for 24 days. The results showed that refined oil underwent higher oxidation than the crude oil, as indicated by the peroxide value (40.55 meq/kg), p-Anisidine value (18.78) and total oxidation value (99.87) in refined oil at day 24. There was no significant difference in the free fatty acid value in refined oil during the accelerated storage. Oleic acid remained the most abundant in the fatty acid composition of kenaf seed oil, followed by linoleic acid and palmitic acid during storage. The unsaturated fatty acids decreased slightly coupled with a slight increase in the saturated fatty acids in kenaf seed oil during storage. Refining process decreased the oxidative stability of kenaf seed oil, but the refined kenaf seed oil was able to maintain good quality in free fatty acid value and fatty acid composition.
\end{abstract}

Keywords: Linoleic acid; oleic acid; refining process; total oxidation value

ABSTRAK

Minyak biji kenaftelah dicadangkan untuk digunakan sebagai minyak makan tetapi terdapat maklumat yang terhad tentang kestabilan oksidatif bagi minyak biji kenaf bertapis. Ujian kestabilan oksidatif telah dilakukan ke atas minyak biji kenaf mentah dan bertapis bawah dipercepatkan penyimpanan pada $65^{\circ} \mathrm{C}$ selama 24 hari. Hasil kajian menunjukkan minyak bertapis menjalani pengoksidaan lebih tinggi daripada minyak mentah seperti yang ditunjukkan oleh nilai peroksida (40.55 meq/kg), p-Anisidine nilai (18.78) dan jumlah nilai pengoksidaan (99.87) dalam minyak disempurnakan pada hari ke-24. Tiada perbezaan yang signifikan dalam lemak nilai asid dalam minyak yang ditapis semasa penyimpanan dipercepatkan. Asid oleik kekal yang paling banyak, diikuti oleh asid linoleik dan asid palmitik semasa penyimpanan. Asid lemak tak tepu menurun sedikit ditambah pula dengan sedikit peningkatan dalam asid lemak tepu dalam minyak biji kenaf semasa penyimpanan. Proses penapisan menurun kestabilan oksidatif bagi minyak biji kenaf, tetapi minyak benih kenaf yang disucikan dapat mengekalkan kualiti yang baik di bebas nilai asid lemak dan lemak komposisi asid.

Kata kunci: Asid linoleik; asid oleik; penapisan proses; pengoksidaan jumlah nilai

\section{INTRODUCTION}

Continuous searching for new sources of edible oil with improved functional properties has focused our attention on the kenaf seeds oil due to its high nutritional composition. Kenaf (Hibiscus cannabinus L.) is a useful fibre plant native to India and Africa. It has been planted as a potential substitution for tobacco plantation in Malaysia (Kaco et al. 2014; Zakaria et al. 2014). Kenaf seeds contain relatively high oil content and its similarity to cottonseed oil proposed that this oil might be used as a potential source of edible oil. Kenaf seed oil is considered nutritionally healthy due to its abundant levels of monounsaturated fatty acid (MUFA) and polyunsaturated fatty acid (PUFA), especially oleic acid $\left(\mathrm{C}_{18: 1}\right)$ and linoleic acid $\left(\mathrm{C}_{18: 2}\right)$. It has been proven that regular consumption of oils with high content of MUFA and PUFA offer cardio protective properties (Nyam et al. 2009). Besides that, kenaf seed oil was found to exhibit high levels of bioactive compounds like polyphenols, tocopherols and phytosterols (Chew et al. 2016a, 2015). Previous studies reported that kenaf seed oil possesses protection effect against ulceration and cholesterol-lowering ability ( $\mathrm{Ng}$ et al. 2015; Nyam et al. 2016).

As kenaf seeds contribute to the considerable waste amount during the harvesting and processing of kenaf, it could be utilized as a cheaper raw material for the production of commercial kenaf seed oil (Chew et al. 2016b). All these interesting characteristics should arouse attention for the usage of kenaf seeds as an alternative source of edible oils. There is an ongoing effort to develop refining technology for each variety of edible oils in order to remove the majority of unwanted components, such as dirt, moisture, gums, waxes, pigments, flavoring substances, trace metals, and free fatty acids (Vaisali et al. 2015).

It is generally known that oxidation is a major cause of deterioration in fat and oils, especially in PUFA, leading to a loss of nutritional value and formation of rancid odors, unpleasant flavors, and in some cases toxic compounds 
(Cho et al. 2015). The hydroperoxides produced by lipid oxidation can decompose into low molecular weight products, such as aldehydes, ketones, alcohols, and carboxylic acids, which some of these volatile compounds affect the flavor in oil product (Richards et al. 2005). Therefore, the evaluation of oxidative stability is a key factor in developing the new oil for food applications. Oxidative stability can be determined by accelerated methods at elevated temperatures in the presence of excess oxygen. Schaal oven test and active oxygen method have been widely used to evaluate the oxidative stability of oil products (Wan 1995).

Chew et al. (2017) reported that the rate of degradation of tocopherols and phytosterols in refined kenaf seed oil was slower than that in the crude oil during the accelerated storage. There is no literature work has been found on the oxidative stability of refined kenaf seed oil. To the best of our knowledge, this study was to evaluate the impact of refining process on the oxidative stability of kenaf seed oil. Peroxide value (PV), $p$-Anisidine value ( $p$-AV), total oxidation value (totox), free fatty acid (FFA) and fatty acid composition were analyzed in the crude and refined kenaf seed oil during accelerated storage.

\section{MATERIALS AND METHODS}

\section{MATERIALS AND CHEMICALS}

Kenaf seeds were obtained from Malaysian Agricultural Research and Development Institute (MARDI), Selangor, Malaysia. All chemicals used were of analytical grade (Merck, Darmstadt, Germany). Fatty acid methyl ester (FAME) standard was the product from Sigma-Aldrich (St. Louis, USA). Acid-activated bleaching earth was obtained from Taiko Clay Marketing Sdn. Bhd. (Perak, Malaysia).

\section{SOLVENT EXTRACTION OF CRUDE KENAF SEED OIL}

Kenaf seeds were ground into fine powder using a grinder (Tefal, French). The oils were extracted by a Soxhlet extractor using hexane at $60^{\circ} \mathrm{C}$ for $3 \mathrm{~h}$ (sample-to-solvent ratio $1: 5, \mathrm{w} / \mathrm{v})$. The solvent was evaporating off using Buchi Multivapor P-6 at $55^{\circ} \mathrm{C}, 241 \mathrm{mbar}$ for $30 \mathrm{~min}$ (BÜCHI Labortechnik AG, Switzerland) to recover the oils. The residual solvent was removed by flushing with $99.9 \%$ nitrogen (Chew et al. 2015).

\section{OIL REFINING PROCESS}

The refining process was conducted according to the chemical refining process reported in the previous study (Chew et al. 2016a). Water degumming with acid pretreatment was applied on the crude kenaf seed oil. The crude oil was acid degummed by adding $0.3 \% \mathrm{w} / \mathrm{w}$ of phosphoric acid ( $85 \%$ concentration) into the crude oil for $10 \mathrm{~min}$ and followed by treating with $3 \% \mathrm{w} / \mathrm{w}$ of Milli-Q water in a heated water bath at $70^{\circ} \mathrm{C}$ for $30 \mathrm{~min}$. The gums were removed from the degummed oil by centrifugation.
Then, the FFA in the degummed oil was neutralized by an excess level of 0.2 to $0.5 \%$ of the stoichiometric quantity of sodium hydroxide solution $\left(12^{\circ}\right.$ Baume $)$ and the soapstock was removed by centrifugation. The neutralized oil was washed with Milli-Q water to remove the residual soap in the oil. The neutralized oil was agitated with $1.2 \% \mathrm{w} / \mathrm{w}$ of Taiko Classic acid-activated bleaching earth at $95^{\circ} \mathrm{C}$ under a reduced pressure of $50 \mathrm{mbar}$ for $30 \mathrm{~min}$. After that, the final deodorization step was carried out in the bleached oil with a lab-scale glass deodorizer at $200^{\circ} \mathrm{C}$ for $1 \mathrm{~h}$. Steam was generated and passed into the oil through a delivery tube and vacuum was applied by means of the vacuum pump.

\section{OXIDATIVE STABILITY UNDER ACCELERATED STORAGE}

The oxidative stability of crude and refined kenaf seed oil were tested under accelerated storage conditions by the Schaal oven test, which used as a rapid method to simulate the storage in real conditions. Duplicate samples of crude and refined kenaf seed oil were stored in universal bottles wrapped in aluminum foil with loosely capped. The oils were then stored in a drying oven (Memmert, USA) at $65^{\circ} \mathrm{C}$ for 24 days, whereby 1 day of storage represents 1 month of storage at room temperature (Iqbal \& Bhanger 2007). A set of duplicated samples was removed from the oven on day $0,6,12,18$, and 24 of the storage and subjected to the analyses.

\section{ANALYTICAL METHODS}

PV was determined according to the AOCS Official Method (AOCS 1998a). p-AV was determined according to the AOCS Official Method Cd 18-90 (AOCS 1998b) using a UV-Vis spectrophotometer (UVmini-1240, Shimadzu Corporation, Japan) at $350 \mathrm{~nm}$. Totox value was calculated from the equation of Totox value $=2 \mathrm{PV}+p$-AV which was adapted from O'Connor et al. (2007). FFA was determined by titration as previously described by AOCS (2000).

\section{FATTY ACID COMPOSITION}

Fatty acid composition was analyzed according to the previously established method (Chew et al. 2016a; Nyam et al. 2009). The FAME was prepared by adding $950 \mu \mathrm{L}$ of n-hexane, $50 \mathrm{mg}$ of oil and $50 \mu \mathrm{L}$ of $30 \mathrm{~mL} / 100 \mathrm{~mL}$ sodium methoxide in methanol. The mixtures were vortexed for $5 \mathrm{~s}$ and then the top layer was filtered through a $0.45 \mu \mathrm{m}$ syringe filter, followed by $1 \mu \mathrm{L}$ was injected into a GC (Agilent Technologies 7890A, USA) equipped with a flame ionization detector (FID), with a split ratio of 50:1. A polar capillary column BPX70 (0.32 mm internal diameter, 30 $\mathrm{m}$ length and $0.25 \mu \mathrm{m}$ film thickness; SGE International Pty. Ltd., Victoria, Australia) was used at a column head pressure of 10 psi. Helium (99.995\%) at approximately $23 \mathrm{~mL} / \mathrm{min}$ (measured at oven temperature $150^{\circ} \mathrm{C}$ ) was used as the carrier gas, and nitrogen (99.999\%) at $20 \mathrm{~mL} /$ min was used as the makeup gas. The FID and injector temperature were both maintained at $220^{\circ} \mathrm{C}$. The initial 
column oven temperature was set at $115^{\circ} \mathrm{C}$, temperature programmed to $180^{\circ} \mathrm{C}$ at $8^{\circ} \mathrm{C} / \mathrm{min}$ and hold for $17 \mathrm{~min}$ and then programmed to $250^{\circ} \mathrm{C}$ at $20^{\circ} \mathrm{C} / \mathrm{min}$. FAME peaks were identified by comparison of retention times to a Supelco FAME mix.

\section{STATISTICAL ANALYSIS}

All experiments were performed in duplicate and measurements were replicated two times. All results were analyzed by one-way analysis of variance (ANOVA) and independent T-test using MINITAB 16 (Minitab Inc, Pennsylvania, USA). Tukey's post hoc test was used to determine the significant difference among the average values in one-way ANOVA. The differences were counted as significant at the level of $p<0.05$.

\section{RESULTS AND DISCUSSION}

\section{PV}

PV is a commonly used method to measure lipid oxidation, and mainly used for measuring the peroxide formation in early stages of oxidation. Lots of peroxides and hydroperoxides were formed as primary oxidation products in oils through autoxidation during the oxidation process. As observed in Figure 1, PV of refined kenaf seed oil was significantly lower $(p<0.05)$ than the crude kenaf seed oil at day 0. Chew et al. (2016) showed that hydroperoxides were strongly reduced by the absorption of hydroperoxides by hydrated gums at the degumming stage and decomposed by the acid activated bleaching earth at bleaching stage during the refining process. However, the $\mathrm{PV}$ of refined oil was increased significantly $(p<0.05)$ from 0.85 to $40.55 \mathrm{meq} / \mathrm{kg}$ oil during the accelerated storage. This is because of the extent of oxidation caused by the formation of hydroperoxides during lipid oxidation. On the other hand, the PV of crude oil was increased from 2.39 to $22.48 \mathrm{meq} / \mathrm{kg}$ oil from day 0 to 18 , but then decreased to 17.19 during the day 24 . This might due to the PV in crude oil had reached the maximum at day 18 and start to decompose into secondary oxidation products (Nor et al. 2008). Besides that, Iqbal and Bhanger (2007) explained that a decrease in PV after reaching its maximum may be due to the volatilization of some breakdown products of lipid hydroperoxides. The PV of crude and refined oils experienced a higher rate of increment from day 0 to 12 . After that, the PV of crude and refined oils from day 12 to 24 were not a significant difference. This may due to the oils have entered the late stages of oxidation.

Compared to the previous study, the PV of refined sunflower oil had reached $173 \mathrm{meq} / \mathrm{kg}$ during the 24 days of accelerated storage (Nyam et al. 2013). The refined kenaf seed oil was more oxidized than the crude oil might due to the removal of phenolic compounds during the refining process. A preliminary study showed that there was a loss of $71.4 \%$ of phenolic compounds in kenaf seed oil after the whole refining process (Chew et al. 2016a). Zacchi and Eggers (2008) explained that the decrease of oxidative stability index of the rapeseed oil after the refining process is due to the phenolic compounds are almost completely removed during the refining process, which has a strong negative effect on the oxidative stability of the oils.

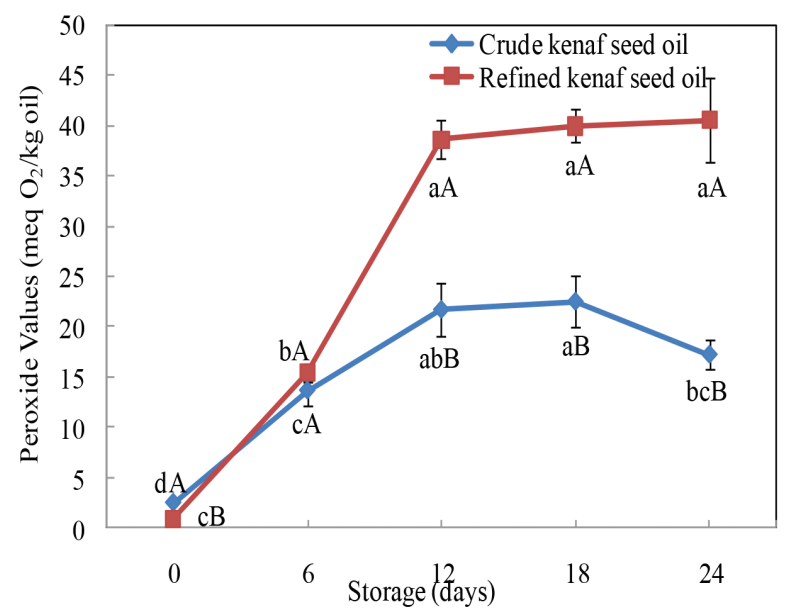

FIGURE 1. PV in crude and refined kenaf seed oils during accelerated storage. Means \pm standard deviations with different superscript letters $a b c d$ indicate significant differences $(p<0.05)$ among different days of the same sample and means \pm standard deviations with different superscript letters $A B$ indicate significant differences $(p<0.05)$ between two samples at the same day of storage

$$
p \text {-AV }
$$

The formed hydroperoxides were no longer assayed as oil oxidation continues, thus $p$-AV is the appropriate method to assess the secondary oxidation products. Figure 2 displays the $p$-AV of crude and refined kenaf seed oil upon accelerated storage. The $p$-AV of refined oil increased from day 0 to 24 . However, the $p$-AV of crude oil increased from day 0 to 18 but then decreased slightly to day 24 . An elevated $p$-AV indicated an increased level of secondary oxidation products in oil, including aldehydes, ketones, and various other substances. The decrease of $p$-AV of crude oil from day 18 to 24 can be explained by further oxidation of aldehydes into carboxylic acids, which caused a decrease in a number of aldehydes in crude oils (Grill et al. 2006). There was no significant difference in the $p$-AV of crude and refined oils at day 0 , but the $p$-AV of refined oil was significantly higher $(p<0.05)$ than the $p$-AV of crude oil from day 6 to 24 .

\section{TOTOX}

totox value indicates the complete oxidation status of oil, with the maximum acceptable level of 30 . Based on Figure 3 , totox value of refined kenaf seed oil increased from day 0 to 24 , whereas the totox value of crude kenaf seed oil increased from day 0 to 18 but then decreased slightly when day 24. The totox values of crude and refined oils undergo a higher rate of increment from day 0 to 12 . After 


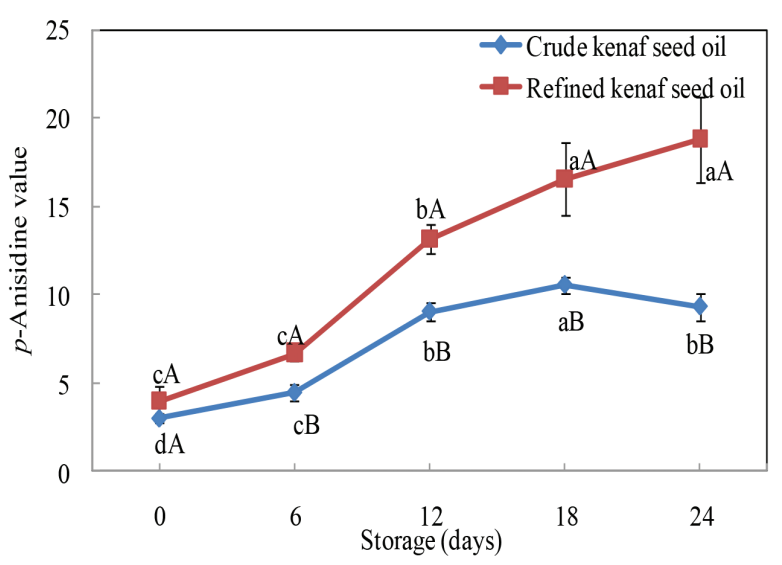

FIGURE 2. $p$-AV in crude and refined kenaf seed oils during accelerated storage. Means \pm standard deviations with different superscript letters $a b c d$ indicate significant differences $(p<0.05)$ among different days of the same sample and means \pm standard deviations with different superscript letters $A B$ indicate significant differences $(p<0.05)$ between two samples at the same day of storage

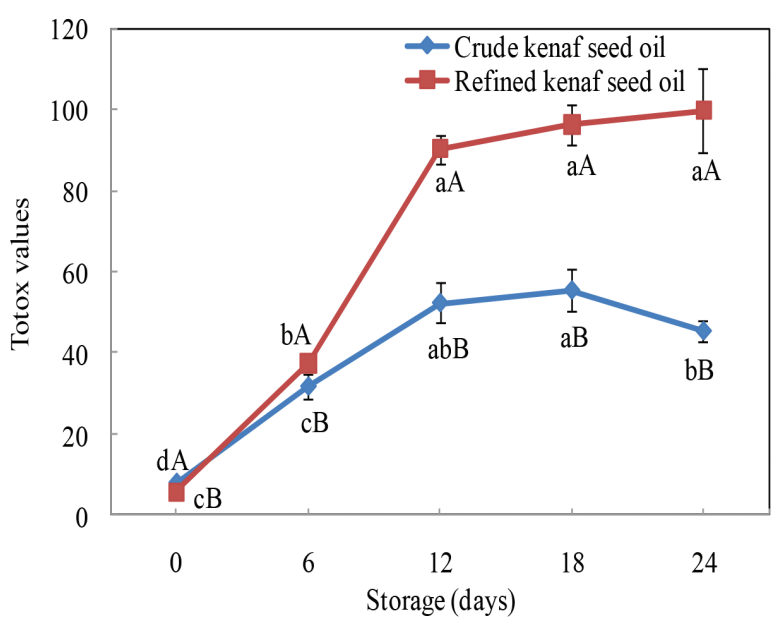

FIGURE 3. Totox values in crude and refined kenaf seed oils during accelerated storage. Means \pm standard deviations with different superscript letters $a b c d$ indicate significant differences $(p<0.05)$ among different days of the same sample and means \pm standard deviations with different superscript letters $A B$ indicate significant differences $(p<0.05)$ between two samples at the same day of storage

day 12 , the oxidation in crude and refined oils occurred much slower. The totox value of refined oil was significantly higher $(p<0.05)$ than the totox value of crude oil from day 6 to 24. This showed that the refined kenaf seed oil had less oxidative stability than the crude oil. It is probably because of the crude oil contains a higher level of natural antioxidants and phosphatides that have synergistic effects on antioxidants (Kreps et al. 2014). Gutierrez et al. (2011) reported that removal of the phenolic compound from olive oil without altering other antioxidant components resulted in the decrease of $50 \%$ of the oil stability. Minor components in the crude oil, which act as potent fat-soluble antioxidants are degraded during the deodorization process due to the high temperature applied (Kumar \& Krishna 2014). However, Nyam et al. (2013) reported that the totox value of refined sunflower oil had reached 360.21 during the 24 days of accelerated storage which was much higher than the totox value of kenaf seed oil in this study. This showed that refined kenaf seed oil can compatible with the refined sunflower oil in the market.

FFA

Besides the direct oxidation, lipid hydrolysis was the dominant reason for the generation of FFA when the oils were entered the second stage of lipid oxidation. Figure 4 shows that the FFA values of all the refined kenaf seed oils were significantly lower $(p<0.05)$ than the crude kenaf seed oil during the 24 days of accelerated storage. The refining process had removed $49.6 \%$ of FFA from the crude oil as observed from the FFA values at day 0 . FFA can act as pro-oxidants in vegetable oils as the carboxylic group accelerates the rate of hydroperoxide decomposition. High FFA value may cause in an undesirable taste and flavor in the vegetable oil (Ghazani et al.2013). Therefore, one of the main considerations in refining process is to remove the FFA content from the crude oils. Neutralization and deodorization are the main stages in the oil refining process to remove FFA. Sodium soaps are formed in the oil by the reaction of FFA and $\mathrm{NaOH}$ in order to remove FFA during neutralization stage. However, vacuum-steam distillation was used at a high temperature to eliminate the FFA and other volatile components during deodorization (Chew et al. 2016a). There was no significant difference in the FFA values in the crude oil during the accelerated storage. These results also showed that the accelerated storage did not have a significant effect on the FFA content

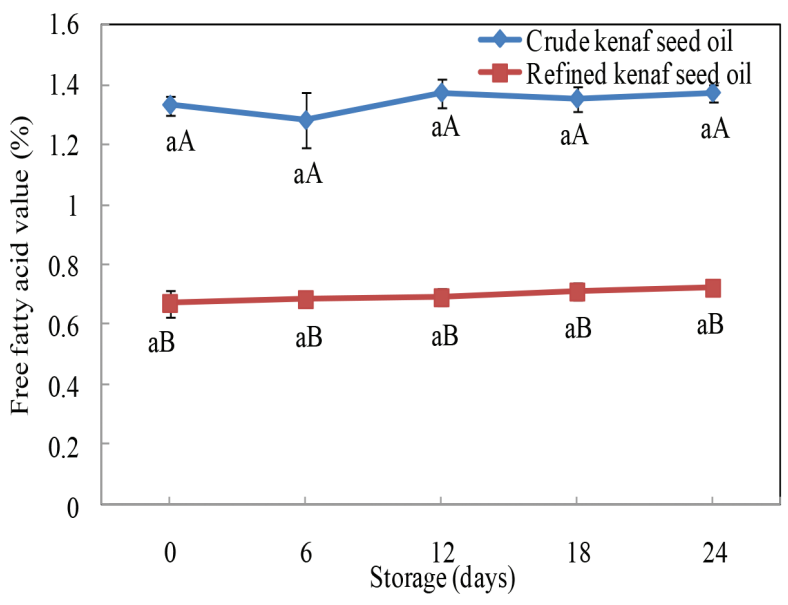

FIGURE 4. FFA in crude and refined kenaf seed oils during accelerated storage. Means \pm standard deviations with the same superscript letter $a$ indicate not significant differences $(p>0.05)$ among different days of the same sample and means \pm standard deviations with different superscript letters $A B$ indicate significant differences $(p<0.05)$ between two samples at the same day of storage 
in kenaf seed oil. This might due to the lower moisture content present in the kenaf seed oil. FFA is produced by hydrolytic rancidity, which is caused by the hydrophilic groups of FFA interact with water molecules (Chew et al. 2016b). The FFA content of refined oil remained lower than $1 \%$ during the accelerated storage. According to Esuoso and Odetokun (1995), the FFA content for edible oil should not exceed 5\%. Moreover, the upper threshold limit for extra-virgin olive oil is $1 \%$ in its FFA content (Besbes et al.2004). This result indicates that the refined oil was acceptable and safe for consumption within a period of 2 years.

\section{FATTY ACID COMPOSITION}

Table 1(A) and 1(B) shows that crude and refined kenaf seed oils were exhibited the same fatty acid profile with high levels of MUFA and PUFA. Oleic acid $\left(\mathrm{C}_{18: \ln 9}\right)$ was the predominant unsaturated fatty acid, followed by linoleic acid $\left(\mathrm{C}_{18: 2 n 6}\right)$ while palmitic acid $\left(\mathrm{C}_{16: 0}\right)$ was the predominant saturated fatty acids in crude and refined kenaf seed oil. The high content of MUFA especially oleic acid is associated with a low risk of coronary heart disease because it helps to lower total cholesterol and low-density lipoprotein cholesterol (Cintra et al. 2006). Linolenic and linoleic fatty acids are known as essential fatty acids as human cannot produce it from the body and must obtain these essential fatty acids from diet. However, low $\alpha$-linolenic acid content makes kenaf seed oil has good storing quality for cooking purposes as $\alpha$-linolenic acid is easier to undergo oxidation (Coetzee et al. 2008).
Upon accelerated storage, there was an increase in palmitic acid and lignoceric acid in the crude and refined oils. Besides that, there was an increase in stearic acid in the crude oil. Overall, the saturated fatty acids were found to be increased during the accelerated storage coupled with a decrease in the PUFA and there was no significant difference $(p>0.05)$ in the MUFA for crude and refined oils. The levels of linoleic acid and $\alpha$-linolenic acid were decreased during the accelerated storage for crude and refined oils. There was a slight increase in oleic acid but a decrease in nervonic acid in the crude oil. On the other hand, oleic acid has decreased in the refined kenaf seed oil, but the total MUFA was not undergoing much variations during the storage.

The detected changes in fatty acids generally agreed with the previous findings. PUFA are more susceptible to oxidation because of its double bond of unsaturated fatty acids was easier to undergo breakage which contributes to lipid oxidation as linoleic acid oxidizes $~ 50$ times than oleic acid (Brinkmann 2000). A slight decrease in linoleic acid and linolenic acid due to the oxidation at a higher temperature resulted in the increase in oleic acid. Nyam et al. (2015) reported that the total MUFA and PUFA in kenaf seed oil were found to be decreased significantly during the accelerated storage caused to the increase in saturated fatty acids. Refined kenaf seed oil was still contained a high proportion of MUFA and PUFA compared to saturated fatty acids after the accelerated storage. This showed that the fatty acid profile of refined kenaf seed oil was kept at good quality during the storage.

TABLE 1. a) Relative percent composition of fatty acids in crude kenaf seed oil during accelerated storage

\begin{tabular}{|c|c|c|c|c|c|}
\hline \multirow{2}{*}{ Fatty acid } & \multicolumn{5}{|c|}{ Storage (days) } \\
\hline & 0 & 6 & 12 & 18 & 24 \\
\hline $\mathrm{C} 14: 0$ & $0.25 \pm 0.00^{\mathrm{a}}$ & $0.24 \pm 0.00^{\mathrm{a}}$ & $0.24 \pm 0.00^{\mathrm{a}}$ & $0.24 \pm 0.01^{\mathrm{a}}$ & $0.24 \pm 0.00^{\mathrm{a}}$ \\
\hline $\mathrm{C} 16: 0$ & $23.32 \pm 0.10^{\mathrm{b}}$ & $23.62 \pm 0.16^{\mathrm{a}}$ & $23.65 \pm 0.10^{\mathrm{a}}$ & $23.90 \pm 0.17^{\mathrm{a}}$ & $23.82 \pm 0.10^{\mathrm{a}}$ \\
\hline C16:1 & $0.62 \pm 0.01^{\mathrm{a}}$ & $0.63 \pm 0.01^{\mathrm{a}}$ & $0.63 \pm 0.01^{\mathrm{a}}$ & $0.63 \pm 0.00^{\mathrm{a}}$ & $0.63 \pm 0.01^{\mathrm{a}}$ \\
\hline $\mathrm{C} 17: 1$ & $0.25 \pm 0.01^{\mathrm{a}}$ & $0.25 \pm 0.00^{\mathrm{a}}$ & $0.25 \pm 0.00^{\mathrm{a}}$ & $0.26 \pm 0.00^{\mathrm{a}}$ & $0.26 \pm 0.00^{\mathrm{a}}$ \\
\hline $\mathrm{C} 18: 0$ & $4.57 \pm 0.03^{b}$ & $4.62 \pm 0.03^{\mathrm{a}}$ & $4.56 \pm 0.02^{\mathrm{b}}$ & $4.63 \pm 0.01^{\mathrm{a}}$ & $4.62 \pm 0.03^{\mathrm{a}}$ \\
\hline C18:1n9 & $33.00 \pm 0.11^{\mathrm{b}}$ & $33.00 \pm 0.06^{\mathrm{b}}$ & $33.35 \pm 0.11^{\mathrm{a}}$ & $33.34 \pm 0.12^{\mathrm{a}}$ & $33.52 \pm 0.09^{\mathrm{a}}$ \\
\hline C18:2n6 & $32.19 \pm 0.13^{\mathrm{a}}$ & $31.85 \pm 0.03^{b}$ & $31.71 \pm 0.11^{\mathrm{bc}}$ & $31.51 \pm 0.02^{\mathrm{d}}$ & $31.61 \pm 0.01^{\mathrm{cd}}$ \\
\hline $\mathrm{C} 18: 3 \mathrm{n} 6$ & $0.87 \pm 0.01^{\mathrm{a}}$ & $0.86 \pm 0.01^{\mathrm{a}}$ & $0.87 \pm 0.01^{\mathrm{a}}$ & $0.87 \pm 0.01^{\mathrm{a}}$ & $0.88 \pm 0.01^{\mathrm{a}}$ \\
\hline $\mathrm{C} 18: 3 \mathrm{n} 3$ & $0.30 \pm 0.01^{\mathrm{a}}$ & $0.28 \pm 0.00^{\mathrm{b}}$ & $0.28 \pm 0.00^{\mathrm{b}}$ & $0.28 \pm 0.00^{\mathrm{b}}$ & $0.28 \pm 0.00^{\mathrm{b}}$ \\
\hline C20:0 & $0.70 \pm 0.01^{\mathrm{a}}$ & $0.69 \pm 0.01^{\mathrm{a}}$ & $0.70 \pm 0.02^{\mathrm{a}}$ & $0.70 \pm 0.01^{\mathrm{a}}$ & $0.71 \pm 0.01^{\mathrm{a}}$ \\
\hline $\mathrm{C} 22: 0$ & $0.35 \pm 0.01^{\mathrm{a}}$ & $0.35 \pm 0.01^{\mathrm{a}}$ & $0.35 \pm 0.01^{\mathrm{a}}$ & $0.35 \pm 0.01^{\mathrm{a}}$ & $0.36 \pm 0.01^{\mathrm{a}}$ \\
\hline $\mathrm{C} 24: 0$ & $0.26 \pm 0.01^{\mathrm{c}}$ & $0.27 \pm 0.01^{\mathrm{c}}$ & $0.30 \pm 0.02^{\mathrm{b}}$ & $0.33 \pm 0.01^{\mathrm{a}}$ & $0.32 \pm 0.00^{\mathrm{a}}$ \\
\hline $\mathrm{C} 24: 1$ & $3.31 \pm 0.03^{\mathrm{a}}$ & $3.34 \pm 0.04^{\mathrm{a}}$ & $3.10 \pm 0.02^{\mathrm{b}}$ & $2.96 \pm 0.01^{\mathrm{c}}$ & $2.74 \pm 0.03^{\mathrm{d}}$ \\
\hline SAT & 29.44 & 29.79 & 29.80 & 30.15 & 30.07 \\
\hline MONO & 37.19 & 37.22 & 37.33 & 37.19 & 37.15 \\
\hline POLY & 33.36 & 32.99 & 32.86 & 32.66 & 32.77 \\
\hline
\end{tabular}

Values are represented as the mean \pm standard deviation of duplicate determinations. Mean values in the same row with different superscripts $\left({ }^{\mathrm{a}, \mathrm{b}, \mathrm{c}, \mathrm{d}}\right)$ are significantly different $(p<0.05)$ 
TABLE 1. b) Relative percent composition of fatty acids in refined kenaf seed oil during accelerated storage

\begin{tabular}{|c|c|c|c|c|c|}
\hline \multirow{2}{*}{ Fatty acid } & \multicolumn{5}{|c|}{ Storage (days) } \\
\hline & 0 & 6 & 12 & 18 & 24 \\
\hline $\mathrm{C} 14: 0$ & $0.20 \pm 0.01^{\mathrm{b}}$ & $0.21 \pm 0.00^{\mathrm{a}}$ & $0.21 \pm 0.00^{\mathrm{a}}$ & $0.21 \pm 0.00^{\mathrm{a}}$ & $0.21 \pm 0.00^{\mathrm{a}}$ \\
\hline C16:0 & $21.94 \pm 0.34^{b}$ & $22.54 \pm 0.08^{\mathrm{a}}$ & $22.74 \pm 0.13^{\mathrm{a}}$ & $22.85 \pm 0.04^{\mathrm{a}}$ & $22.80 \pm 0.04^{\mathrm{a}}$ \\
\hline C16:1 & $0.59 \pm 0.01^{\mathrm{b}}$ & $0.60 \pm 0.00^{\mathrm{a}}$ & $0.61 \pm 0.00^{\mathrm{a}}$ & $0.61 \pm 0.00^{\mathrm{a}}$ & $0.61 \pm 0.00^{\mathrm{a}}$ \\
\hline $\mathrm{C} 17: 1$ & $0.24 \pm 0.00^{\mathrm{b}}$ & $0.25 \pm 0.00^{\mathrm{a}}$ & $0.25 \pm 0.00^{\mathrm{a}}$ & $0.25 \pm 0.00^{\mathrm{a}}$ & $0.25 \pm 0.00^{\mathrm{a}}$ \\
\hline $\mathrm{C} 18: 0$ & $4.33 \pm 0.01^{\mathrm{b}}$ & $4.37 \pm 0.01^{\mathrm{b}}$ & $4.39 \pm 0.03^{\mathrm{ab}}$ & $4.45 \pm 0.05^{\mathrm{a}}$ & $4.37 \pm 0.01^{\mathrm{b}}$ \\
\hline C18:1n9 & $35.11 \pm 0.37^{\mathrm{a}}$ & $34.63 \pm 0.04^{b}$ & $34.76 \pm 0.08^{\mathrm{ab}}$ & $34.72 \pm 0.12^{\mathrm{ab}}$ & $34.96 \pm 0.06^{\mathrm{ab}}$ \\
\hline C18:2n6 & $32.32 \pm 0.08^{\mathrm{a}}$ & $32.11 \pm 0.01^{\mathrm{b}}$ & $31.65 \pm 0.05^{\mathrm{c}}$ & $31.52 \pm 0.03^{\mathrm{cd}}$ & $31.38 \pm 0.14^{\mathrm{d}}$ \\
\hline C18:3n6 & $0.84 \pm 0.01^{\mathrm{a}}$ & $0.83 \pm 0.00^{\mathrm{a}}$ & $0.83 \pm 0.01^{\mathrm{a}}$ & $0.83 \pm 0.00^{\mathrm{a}}$ & $0.84 \pm 0.00^{\mathrm{a}}$ \\
\hline $\mathrm{C} 18: 3 \mathrm{n} 3$ & $0.29 \pm 0.00^{\mathrm{a}}$ & $0.28 \pm 0.00^{\mathrm{b}}$ & $0.27 \pm 0.00^{c}$ & $0.27 \pm 0.00^{c}$ & $0.27 \pm 0.00^{c}$ \\
\hline C20:0 & $0.68 \pm 0.02^{\mathrm{a}}$ & $0.68 \pm 0.01^{\mathrm{a}}$ & $0.68 \pm 0.01^{\mathrm{a}}$ & $0.68 \pm 0.00^{\mathrm{a}}$ & $0.68 \pm 0.00^{\mathrm{a}}$ \\
\hline C22:0 & $0.34 \pm 0.01^{\mathrm{a}}$ & $0.34 \pm 0.01^{\mathrm{a}}$ & $0.34 \pm 0.01^{\mathrm{a}}$ & $0.34 \pm 0.00^{\mathrm{a}}$ & $0.34 \pm 0.00^{\mathrm{a}}$ \\
\hline $\mathrm{C} 24: 0$ & $0.37 \pm 0.02^{\mathrm{d}}$ & $0.40 \pm 0.01^{\mathrm{c}}$ & $0.45 \pm 0.01^{\mathrm{b}}$ & $0.47 \pm 0.01^{\mathrm{b}}$ & $0.51 \pm 0.02^{\mathrm{a}}$ \\
\hline $\mathrm{C} 24: 1$ & $2.76 \pm 0.13^{\mathrm{a}}$ & $2.78 \pm 0.03^{\mathrm{a}}$ & $2.81 \pm 0.03^{\mathrm{a}}$ & $2.81 \pm 0.02^{\mathrm{a}}$ & $2.78 \pm 0.04^{\mathrm{a}}$ \\
\hline SAT & 27.85 & 28.53 & 28.81 & 29.00 & 28.91 \\
\hline MONO & 38.70 & 38.25 & 38.43 & 38.38 & 38.60 \\
\hline POLY & 33.45 & 33.22 & 32.76 & 32.62 & 32.49 \\
\hline
\end{tabular}

Values are represented as the mean \pm standard deviation of duplicate determinations. Mean values in the same row with different superscripts ( ${ }^{\mathrm{a}, \mathrm{b}, \mathrm{c}, \mathrm{d}}$ ) are significantly different $(p<0.05)$

\section{CONCLUSION}

The refined kenaf seed oil showed less oxidative stability than the crude kenaf seed oil. The PV, $p$-AV, and TOTOX value of refined kenaf seed oil was significantly higher than crude oil after the 24 days of accelerated storage. However, there was no significant difference in the free fatty acid content of refined kenaf seed oil during the accelerated storage. The fatty acid composition in refined oil showed that it is suitable to be used as cooking oil. The MUFA and PUFA decreased $0.1 \%$ and $0.96 \%$, respectively, coupled with an increase of $1.06 \%$ in saturated fatty acids after accelerated storage. This study showed that the refined kenaf seed oil showed less oxidative stability than the crude kenaf seed oil, but the refined oil was able to maintain good quality in FFA and fatty acid composition. Future work can be considered looking for the optimum parameters of refining process to get the refined kenaf seed oil with improved oxidative stability.

\section{ACKNOWLEDGEMENTS}

Financial support of this work by internal funding from CERVIE UCSI University (Proj-In-FAS-053) is gratefully acknowledged.

\section{REFERENCES}

AOCS. 2000. Peroxide value acetic acid-chloroform Method Cd 8-53. In Official Methods and Recommended Practices of the American Oil Chemists' Society, edited by Firestone, D. Champaign: AOCS Press.

AOCS. 1998a. Free fatty acids in crude and refined oils method 26.042. In Official Methods and Recommended Practices of the American Oil Chemists' Society, edited by Firestone, D. Champaign: AOCS Press.

AOCS. 1998b. p-Anisidine value method Cd 18-90. In Official Methods and Recommended Practices of the American Oil Chemists' Society, edited by Firestone, D. Champaign: AOCS Press.

Besbes, S., Blecker, C., Deroanne, C., Lognay, G., Drira, N-E. \& Attia, H. 2004. Quality changes and oxidative stability of date seed oil during storage. Food Science and Technology International 10: 333-338.

Brinkmann, B. 2000. Quality criteria of industrial frying oils and fats. European Journal of Lipid Science and Technology 102: 539-541.

Chew, S.C. \& Nyam, K.L. 2016. Oxidative stability of microencapsulated kenaf seed oil using co-extrusion technology. Journal of American Oil Chemists' Society 93(4): 607-615.

Chew, S.C., Tan, C.P. \& Nyam, K.L. 2017. Comparative study of crude and refined kenaf (Hibiscus cannabinus L.) seed oil during accelerated storage. Food Science and Biotechnology 26(1): 63-69.

Chew, S.C., Tan, C.P., Long, K. \& Nyam, K.L. 2016. Effect of chemical refining on the quality of kenaf (Hibiscus cannabinus) seed oil. Industrial Crops and Products 89: 59-65.

Chew, S.C., Tan, C.P., Long, K. \& Nyam, K.L. 2015. In-vitro evaluation of kenaf seed oil in chitosan coated-high methoxyl pectin-alginate microcapsules. Industrial Crops and Products 76: $230-236$.

Cho, S., Kim, J., Han, D., Lim, H.J., Yoon, M., Park, J., Yang, H., Lee, S.H., Noh, B.Y., Park, E., Yoo, H., Baek, J. \& Shin, E.C. 2015. Thermal oxidative stability of corn oil in ultrahigh temperature short-time processed seasoned layer. Food Science and Biotechnology 24: 947-953. 
Cintra, D.E., Costa, A.V., Peluzio Mdo, C., Matta, S.C., Silva, M.J. \& Costa, N.M. 2006. Lipid profile of rats fed highfat diets based on flaxseed, peanut, trout or chicken skin. Nutrition 22: 197-205.

Coetzee, R., Labuschagne, M.T. \& Hugo, A. 2008. Fatty acid and oil variation in seed from kenaf (Hibiscus cannabinus L.). Industrial Crops and Products 27: 104-109.

Esuoso, K.O. \& Odetokun, S.M. 1995. Proximate chemical composition and possible industrial utilization of Biphiasapida seed oils. Rivista Italina Delle Sostanze Grasse 72: 311-313.

Ghazani, S.M., García-Llatas, G. \& Marangoni, A.G. 2013. Minor constituents in canola oil processed by traditional and minimal refining methods. Journal of American Oil Chemists' Society 90: 743-756.

Grill, J.M., Ogle, J.W. \& Miller, A.M. 2006. An efficient and practical system for the catalytic oxidation of alcohols, aldehydes, and $\alpha, \beta$-unsaturated carboxylic acids. Journal of Organic Chemistry 71: 9291-9296.

Gutierrez, F., Arnaud, T. \& Garrido, A. 2011. Contribution of polyphenols to the oxidative stability of virgin olive oil. Journal of the Science of Food and Agriculture 81: 14631470 .

Iqbal, S. \& Bhanger, M.I. 2007. Stabilization of sunflower oil by garlic extract during accelerated storage. Food Chemistry 100: 246-254.

Kaco, H.,Zakaria, S., Razali, N.F., Chia, C.H., Zhang, L. \& Jani, S.M. 2014. Properties of cellulose hydrogel from kenaf core prepared via pre-cooled dissolving method. Sains Malaysiana 43(8): 1221-1229.

Kreps, F., Vrbiková, L. \& Schmidt, Š. 2014. Influence of industrial physical refining on tocopherol, chlorophyll and betacarotene content in sunflower and rapeseed oil. European Journal of Lipid Science and Technology 116: 1572-1582.

Kumar, P.K.P. \& Krishna, A.G.G. 2014. Physico-chemical characteristics and nutraceutical distribution of crude palm oil and its fractions. Grasas y Aceites 65: e018.

Ng, S.K., Tee, A.N., Lai, C.L.E., Tan, C.P., Long, K. \& Nyam, K.L. 2015. Anti-hypercholesterolemic effect of kenaf (Hibiscus cannabinus L.) seed on high-fat diet Sprague Dawley rats. Asian Pacific Journal of Tropical Medicine 8(1): 6-13.

Nor, F.M., Mohamed, S., Idris, N.A. \& Ismail, R. 2008. Antioxidative properties of Pandanus amaryllifolius leaf extracts in accelerated oxidation and deep frying studies. Food Chemistry 110: 319-327.

Nyam, K.L., Tang, J.L.K. \& Long, K. 2016. Anti-ulcer activity of Hibiscus cannabinus and Hibiscus sabdariffa seeds in ulcer-induced rats. International Food Research Journal 23(3): 1164-1172.

Nyam, K.L., Tan, C.H. \& Long, K. 2015. Effect of microwave pretreatment on stability of kenaf (Hibiscus cannabinus L.) seed oil upon accelerated storage. International Food Research Journal 22(5): 1898-1905.
Nyam, K.L., Wong, M.M., Long, K. \& Tan, C.P. 2013. Oxidative stability of sunflower oils supplemented with kenaf seeds extract, roselle seeds extract and roselle extract, respectively under accelerated storage. International Food Research Journal 20(2): 695-701.

Nyam, K.L., Tan, C.P., Lai, O.M., Long, K. \& Che Man, Y.B. 2009. Physicochemical properties and bioactive compounds of selected seed oils. LWT- Food Science and Technology 42(8): 1396-1403.

O'Connor, C.J., Lal, S.N.D. \& Eyres, L. 2007. Handbook of Australasian Edible Oils. Auckland: Oils and Fats Specialist Group of NZIC.

Richards, A., Wijesunderaa, C. \& Salisbury, P. 2005. Evaluation of oxidative stability of canola oils by headspace analysis. Journal of American Oil Chemists' Society 82: 869-874.

Vaisali, C., Charanyaa, S., Belur, P.D. \& Regupathi, I. 2015. Refining of edible oils: A critical appraisal of current and potential technologies. International Journal of Food Science and Technology 50: 13-23.

Wan, P.J. 1995. Accelerated stability methods. In Methods to Assess Quality and Stability of Oils and Fat-Containing Foods, edited by Warner, K. \& Eskin, N.A.M. Champaign: AOCS Press.

Zacchi, P.\& Eggers, R. 2008. High-temperature pre-conditioning of rapeseed: A polyphenol-enriched oil and the effect of refining. European Journal of Lipid Science and Technology 110: 111-119.

Zakaria, S., Roslan, R., Amran, U.A., Chia, C.H. \& Bakaruddin, S.B. 2014. Characterization of residue from EFB and kenaf core fibres in the liquefaction process. Sains Malaysiana 43(3): 429-435.

Sook Chin Chew \& Kar Lin Nyam*

Department of Food Science and Nutrition

Faculty of Applied Sciences, UCSI University

56000 Kuala Lumpur, Federal Territory

Malaysia

\section{Chin Ping Tan}

Department of Food Technology

Faculty of Food Science and Technology

43400 UPM Serdang, Selangor Darul Ehsan

Malaysia

*Corresponding author; email: nyamkl@ucsiuniversity.edu.my

Received: 21 September 2017

Accepted: 31 October 2018 